\title{
In Search of Training Gestures: What Regularities can be observed when Teaching how to Teach Written Production?
}

\author{
Roxane Gagnon* \\ Véronique Laurens** \\ Joaquim Dolz***
}

\begin{abstract}
Based on an empirical research on teacher training practices in Switzerland that brings together 28 training sequences on written production, this paper proposes an overview of the professional gestures that trainers develop while preparing future teachers. Six major professional gestures organize the dynamics of the observed trainer's formation and action. Two gestures take place outside the classroom: planning and evaluating of the training work. Four gestures take place during the implementation of sequences in the teacher's presence: conceptualizing of writing and of teaching and learning; mobilization of practices and experiences of written production at class; equipping with resources and tools for the teaching of writing; regulating of teachers' learning and practices. This paper brings examples to illustrate the trainer's action on the mastering of the written production. The results showed the importance of the trainer's action to develop the necessary professional skills for the written production teaching.
\end{abstract}

Keywords: Teacher training practices. Training sequences. Written production. Professional gestures.

\section{Em busca de gestos de formação: quais regularidades podem ser observadas no ensino de produção escrita?}

\begin{abstract}
Resumo
A partir de uma pesquisa empírica sobre as práticas de formação do professorado na Suíça que reúne 28 sequências de formação sobre a produção escrita, este artigo propõe uma visão geral dos gestos profissionais que desenvolvem os formadores ao preparar os futuros docentes. Seis grandes gestos profissionais organizam a dinâmica da formação observada e o agir do formador. Dois gestos se realizam fora das aulas: planificação e avaliação do trabalho de treinamento. Quatro gestos têm lugar no curso da implementação das sequências em presença dos docentes: conceptualização da escrita e do seu ensino e aprendizagem, mobilização das práticas e experiências da produção escrita na aula, equipar com recursos e ferramentas para o ensino a escrita, regulação das aprendizagens e das práticas dos professores. O artigo ilustra com exemplos o agir do formador no domínio da produção escrita. Os resultados da pesquisa mostram a importância do agir do formador para o desenvolvimento de competências profissionais para o ensino da produção escrita.
\end{abstract}

Palavras-chave: Práticas de formação de professores. Sequências de treinamento. Produção escrita. Gestos profissionais.

Recebido: 15/04/2019

Aceito: 15/07/2019

\footnotetext{
* Haute École pédagogique de Lausanne.

** Paris III, Sorbonne Nouvelle

*** Université de Genève
} 
The identification and description of gestures clarify the dynamic involved in a training process. In their work, teachers transmit ways of speaking, ways of doing and ways of interacting: by "gestures", we refer to those concrete manners of saying, doing and interacting. In this article, the observation of the teacher's training practices on the subject of written production gives us the possibility to identify and characterize a certain number of didactical gestures in the context of teacher education.

\section{Why use the word "gestures" to analyse teaching or training practices?}

At first, the concept of didactic or professional gesture can be related to the teacher's voice and body: those are his main working tools. Using his voice and his body, the teacher transmits information and knowledge, supports the conduct of the lesson and the regulation of the learning interactions. In that sense, we can draw a parallel between a comedian's and a teacher's work: the teacher's gestures have a theatrical value during the teaching performance. Vocal and physical gestures give a presence to teachers, they structure the relationship between teachers and pupils and settle the teachers' authority (RUNTZ-CHRISTAN, 2000; TELLIER \& CADET, 2014). The choice of the word "gesture" reflects the pragmatic dimension of the teaching activity: gestures are verbal and corporal indicators of the teacher's skill, as they provide signs of what has to be seen, understood, perceived and exercised (BUCHETON, 2008). Moreover, Jorro (2002; 2004) defines teaching professional gestures as a repertoire of routines and working gestures set in an epistemological framework.

In a subject didactic perspective, teaching gestures consist in ways of speaking, of doing, of being in order to insure the communication of an object of knowledge. For Schneuwly and Dolz (2009), "the heart of teaching lies in two fundamental gestures: make present the object to be taught and draw attention to the taught object as a whole or to some of its dimensions". Sensevy defines the concept of teaching gesture as a mode of transformation of the knowledge related to a school content in order to ensure his communicability. For Sensevy (2001), it's the knowledge that shapes the gesture, and in order to perform the gesture efficiently, one needs to master the appropriate vocabulary and language. In addition to these skills, gestures must be thought within "the semiotic tools that crystallize the knowledge involved and that allows their expression" (SENSEVY, 2010, p. 6). A teaching gesture can be associated with a specific didactic strategy that updates the object of knowledge in the didactic transaction, by means of a learning game.

Two approaches can be used to analyse gestures. The first step is to pay attention to simple and repetitive acts or routines. A full range of motor acts then appear: formulation of instructions, use of the chalkboard, addressing questions, asking students to answer a question etc. In this first approach, we focus on recurrent gestures. In the second approach, the emphasis is put on more situated gestures: we observe gestures in relation to a specific method, a specific object, a specific group of knowledge. In that way, professional gestures act as "technique or art $d u$ faire that answers issues of specific situations" (SENSEVY, 2007). So gestures carry meanings: their action transform the meanings given to objects by the students in a shared meaning process close to social practices of reference. This definition of gestures is similar to the concept of "social mimesis", as it contributes to explain the transmission process and the social heritage of the professional activity (CROCE-SPINELLY, 2014).

In sum, the concept of teaching gestures refers to a specific language, a voice, a body, actions, routines, and semiotic tools that shape the knowledge to be learnt. Gestures are ways of interacting, by ways of doing and saying that participate in the elaboration of the object of knowledge (SCHNEUWLY \& DOLZ, 2009). 


\subsection{A System of Teaching Gestures}

Many works have contributed to identify teaching gestures. Bruner (1983) brought to light different scaffolding gestures that teachers use to guide the young pupil's work. To analyse teaching practice, Jorro (2002; 2004) elaborated a "matrix of language activity" divided in four gestures: linguistic, staging, adjustment and ethical gestures. Bucheton's model of teacher's action is organized as follows: piloting gestures for control and organization of the classroom learning progress; atmosphere gestures to maintain a good working relationship between students; waving gestures to create consistency of what is happening in the classroom; scaffolding gestures to support students in the task component that exceeds their initial capabilities (BUCHETON, 2008; BUCHETON \& SOULÉ, 2009; BUCHETON, ALEXANDRE \& JURADO, 2014).

Based on those previous works and others (BERNIÉ \& GOIGOUX, 2005; AEBY DAGHÉ \& DOLZ, 2009; DUFAYS, 2019; JAUBERT \& REBIÈRE, 2005; SCHUBAUER-LEONI, LEUTENNEGERRIHS, LIGOZAT \& FLÜCKIGER, 2007; SILVA, 2013), we developed a descriptive model of professional gestures in accordance with our social interactionist framework (BRONCKART, 1997). Our descriptive model was the result of an empirical study involving 27 teaching sequences in French classrooms (SCHNEUWLY \& DOLZ, 2009). This descriptive model includes two fundamental teaching gestures: pointing-decomposition gesture and display gesture (SCHNEUWLY, 2000). With those two gestures, the teacher outlines the learning environment, decomposes and points out objects of knowledge to be learned. Four other gestures were also identified: setting of the didactic device; memory recall; regulation; institutionalization. When he sets the didactic device, the teacher creates a learning environment using semiotic tools (materials, instructions, pedagogical formulas) that lead the pupil's attention to certain dimensions of the taught object. By recalling the student's memory, teachers call for memories of previous activities in order to anticipate the following work. Regulation gestures include all forms of information obtained during the student's progress and all forms of adjustments made by the teacher in order to facilitate the realization of school tasks. Institutionalization, according to previous works by Brousseau (1998) and Sensevy (2001), establishes generalizations on taught knowledge. Institutionalization gestures set a common culture in the classroom and point out which taught knowledge and skills are transferable to other contexts.

\subsection{From teaching gestures to training gestures?}

When we draw a comparison between the teacher's context of education and the teaching context, which similarities, which differences can be observed regarding professional gestures? In both contexts, the work of the professional is the same: acting as a transformation agent, using semiotic tools, in order to produce a complex sequence of superior psychic functions. For a teacher's trainer, those superior skills can be associated with the written production teaching or with the understanding of disciplinary concepts. In this way, one of the key distinctions between training and teaching gestures lies in the secondarisation of teaching theories and practices (JAUBERT \& REBIÈRE, 2005).

\section{Methodology}

Our data was collected in all teacher training institutions situated in French-speaking Switzerland: universities or colleges of dedicated to the education of teachers in Berne, Fribourg, Geneva, Jura, 
Neuchâtel, Vaud and Valais. Our objective was to obtain a sample of all training practices on one specific object - written production teaching - during the 2009-2010 academic year. We conducted preliminary interviews with trainers and the head of training in these institutions in order to identify all training units related to French didactic and written production. We reconstructed the written production curriculum in each institution. Then, in order to understand and describe the written production teaching in terms of what is taught and how it is taught, we filmed all the practices implemented by the teacher's trainers. We collected data in order to be able to follow all the training sessions followed by a student. For example, if the training unit included a field experience, we would follow the student at school during the internship. In spite of technical issues, slight communication issues, omission of a couple of sessions, we were able to reconstruct and to document all the training practices related to written production teaching. The following table gives an overview of the total data collected, taped or reconstructed:

\begin{tabular}{|c|c|c|c|c|c|}
\hline & Institution & $\begin{array}{c}\text { Number of } \\
\text { sessions filmed }\end{array}$ & $\begin{array}{l}\text { Number of } \\
\text { training sessions } \\
\text { reconstituted }\end{array}$ & $\begin{array}{l}\text { Number of } \\
\text { lessons filmed } \\
\text { during school } \\
\text { internship }\end{array}$ & $\begin{array}{c}\text { Number } \\
\text { of lessons } \\
\text { reconstituted } \\
\text { during school } \\
\text { internship }\end{array}$ \\
\hline \multirow{6}{*}{ 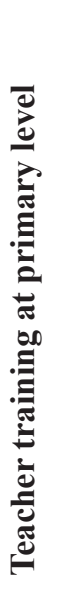 } & HEP BEJUNE & 6 sessions: $14 \mathrm{~h} 15$ & 2 sessions: $3 \mathrm{~h} 00$ & 2 lessons: $3 \mathrm{~h} 36$ & 2 lessons: 1 h30 \\
\hline & HEP Fribourg & 12 sessions: $25 \mathrm{~h} 33$ & & 5 lessons: $3 \mathrm{~h} 40$ & \\
\hline & $\begin{array}{l}\text { University of } \\
\text { Geneva }\end{array}$ & 35 sessions: $43 \mathrm{~h} 23$ & 1 session: $1 \mathrm{~h}$ & 9 lessons: 8 h22 & \\
\hline & HEP Vaud & 24 sessions: $31 \mathrm{~h} 47$ & 4 sessions: $6 \mathrm{~h}$ & & \\
\hline & HEP Valais & 9 sessions: $11 \mathrm{~h} 57$ & & & 6 lessons: $4 \mathrm{~h} 30$ \\
\hline & $\begin{array}{l}\text { Total } \\
\text { primary }\end{array}$ & $\begin{array}{l}86 \text { sessions: } \\
126 \mathrm{~h} 55\end{array}$ & 7 sessions: $10 \mathrm{h00}$ & $\begin{array}{l}16 \text { lessons: } \\
15 \mathrm{~h} 38\end{array}$ & 8 lessons: 6 h00 \\
\hline \multirow{6}{*}{ 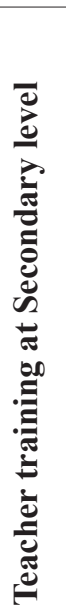 } & $\begin{array}{l}\text { HEP } \\
\text { BEJUNE }\end{array}$ & 3 sessions: $4 \mathrm{~h} 20$ & & & \\
\hline & $\begin{array}{l}\text { University of } \\
\text { Fribourg }\end{array}$ & 7 sessions: $6 \mathrm{~h} 27$ & 1 session: 1 h30 & & \\
\hline & $\begin{array}{l}\text { University of } \\
\text { Geneva }\end{array}$ & 2 sessions: $26 \mathrm{~h} 15$ & & 3 lessons: $2 \mathrm{~h} 56$ & \\
\hline & HEP Vaud & 2 sessions: 3 h06 & 1 session: $1 \mathrm{~h} 30$ & & \\
\hline & HEP Valais & 11 sessions: $21 \mathrm{~h} 50$ & & & \\
\hline & Total secondary & $\begin{array}{l}39 \text { sessions: } \\
61 \mathrm{~h} 58\end{array}$ & 2 sessions: 3 h00 & 3 lessons: 2 h56 & \\
\hline & TOTAL & $\begin{array}{l}125 \text { sessions: } \\
188 \mathrm{~h} 53\end{array}$ & 9 sessions: $13 \mathrm{~h} 00$ & $\begin{array}{l}19 \text { lessons: } \\
18 h 34\end{array}$ & 8 lessons: $6 h 00$ \\
\hline
\end{tabular}


In sum, for teacher training at Primary level, 86 training sessions and 16 lessons, of a total of 142 hours, were filmed and transcribed. For teacher training at Secondary level, we recorded 39 training sessions and 3 lessons, for a total of 65 hours. The combination of the data filmed and reconstituted gives us a sum of 226 hours. From this corpus, we were able to delimit 28 training sequences: ${ }^{1} 18$ at the primary level and 10 at the secondary level.

In order to characterize training gestures and to understand the context in which they appear, we have chosen to analyse both declared and effective training practices. This corpus of data gives us access to every step in the work of the teacher's trainer as he addresses the topic of written production teaching. In order to seize the training gestures, we apply a content analysis approach to infer all ways of speaking or doing that are recurrent within the transcripts. Two key indicators enabled us to identify the training gestures: categories of knowledge and temporality. Our preliminary analysis of the context, based on the study of institutional documents (training programs, websites) (GAGNON \& SURIAN, 2017) and previous works on the subject pointed out a taxonomy of five categories of knowledge (CHEVALLARD, 1999; LENOIR \& VANHULLE, 2006; DESJARDINS \& DEZUTTER, 2009; GOIGOUX, RIA \& TOCZEK-CAPELLE, 2009; HOFSTETTER \& SCHNEUWLY, 2009): institutional knowledge; subject knowledge; knowledge on learning process and on pupils; teaching knowledge; knowledge on teaching practices. Regarding temporality, we assume that a training gesture cannot be done in an isolated way, working as a part of a system of gestures. Our delimitation of training gestures is also achieved by asking: (1) In which phase of the training sequence does the gesture appear? (2) What is the role and the function of the gesture in the dynamic of the sequence?

\section{Six main training gestures related to written production teaching}

Our analyses lead us to identify a six main training gestures system; all of those gestures contribute to the dynamic of transformations of a specific training object: written production teaching. Indeed, each gesture is a key feature to understand how the trainer's action contributes to build new meanings on this training object. Figure 1 shows how the six main gestures are organized and related to each other:

Figure 1: Six main training gesture organized in a system

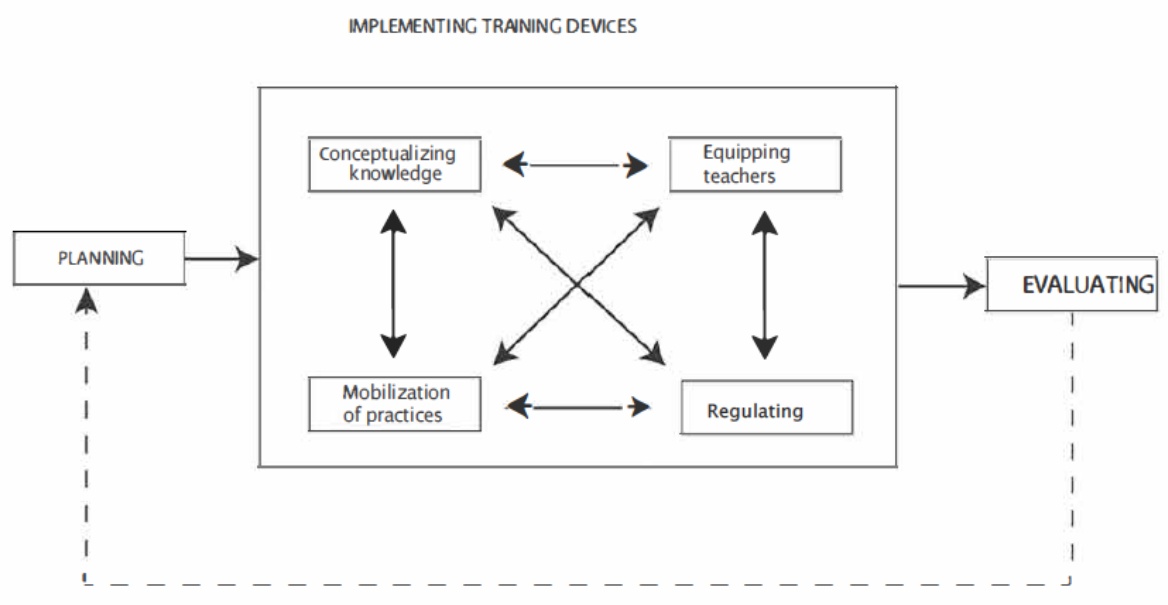

Source: Adapted and translated figure of Dolz, J. \& Gagnon, R. (2018).

1 The criteria used to determine a training sequence are the same as the one used for a teaching sequence: an organized sequence of activities related to a specific taught object, with a beginning and an end. 
The first main gesture identified in the data corpus is planning. It refers to all the actions taken towards the elaboration of the training project: selection of contents as much as distribution of contents according to the calendar.

The second gesture we identified is evaluating. This gesture appears in the last phase of the training unit: it includes any item concerning the assessment of training activities. This assessment takes several forms according to the actors involved. As it includes training process retroactions, this gesture impacts all other gestures.

Four main gestures appear during the training unit. Those four gestures do not follow a preset order like the previous two gestures, although conceptualizing knowledge and equipping teachers gestures provide a foundation for this two following gestures: mobilization of practices and regulating. The conceptualizing knowledge gesture provides a conceptual framework that develops the epistemology of school subjects or academic knowledge regarding the written production teaching. The equipping teachers gesture concerns the development of teaching materials or devices in order to create a good learning environment for written production. Both mobilization of practices and regulating gestures serve to another trainee activity purpose as they provide the implementation and regulation context for student competencies.

\section{Training gestures characterization and illustration}

The various occurrences of the six main training gestures show how the different categories of knowledge, intertwined in every training activity, circulate and are transposed (DUGAL \& LÉZIART, 2004; GAGNON, 2010). Furthermore, the details of each gesture enable us to consider the particular role and status of the trainees during their professional course.

\subsection{Planning}

The planning gesture refers to the overall planning of knowledge contents and instructional approaches, building long-term progression and short-term programming. This gesture occurs before the trainer's interaction with his students. By mobilizing this gesture, the trainer acts as an engineer: he conceives, creates, organizes and directs the training unit in agreement with the students' needs.

We collected traces of this gesture during the interviews with the trainers, but also from the institutional documents in which the preliminary planning is visible. We discovered that many items act as filters of the planning gesture, such as the method of exposition of the contents (seminar, lecture course, practical work, interview between the trainer and the trainee); the timescale envisioned; the possible inclusion of the planning in a larger unit (is the training unit autonomous or part of a larger sequence?); practical issues such as the number of students, the time spent in the training institution and in the internship, the number of credits allocated and material conditions. In the interviews conducted with the trainers, those items are considered as institutional constraints.

The planning gesture involves all training preparations: coordination among the actors involved; update of the e-learning platform, preparation and dissemination of information materials. The document produced by the trainers in the preparation phase is important insofar as it serves as an implicit contract with the trainees.

- Our data shows the planning gesture is done in four main ways:

- Content and method selection;

- Didactic presentation of contents and methods;

- Curriculum organization; 
- Exposure of the training program.

The following extract shows how a female trainer, involved in primary teachers' education, identifies and selects the content and the training method in order to relate those contents and methods to a conceptual framework. She says the lecture courses focus mainly on the teaching of continuous reading - only a quarter of the lecture courses is allocated to the written production teaching. She also brings to light two writing models: the textual genres according to Schneuwly's (1988) and Bucheton's model engaging in an intermediate writing process (2014). She also mentioned that they use both Ferreiro's (1998) and Frith's (1980) models to explain how children begin to learn to write. She also mentioned that a part of the lecture course is devoted to the presentation of the institutional program.

\section{Corpus extract 1: Planning the training for students in primary education}

Et puis ensuite donc pour les $+3+6$ on insiste pas mal sur l'enseignement continué de la lecture / et puis pour le quart qui concerne la production textuelle et c'est ce qui t'intéresse et ben c'est la même chose quoi on définit d'abord qu'est-ce qu'écrire avec différents modèles alors évidemment moi j'prends l'article de Schneuwly par exemple sur qu'est-ce qu'écrire qui parle des genres et caetera mais on donne aussi d'autres points de vue j'pense par exemple à un point de vue de Bucheton écrire c'est toujours dire je et caetera $\downarrow$ / donc on essaie quand même chaque fois de donner des points de vue différents sur les choses même si évidemment on privilégie pas mal la conception genevoise à vrai dire mais on essaie quand même de ne pas donner qu'un modèle $\downarrow$ / et puis après qu'est-ce qu'apprendre à écrire alors on donne aussi l'apprentissage de la lecture on parle des euh des modèles des théories de Ferreiro on parle des théories des cognitivistes le modèle de Frith des choses comme ça et puis enseigner la lecture ben là on reprend les aspects de programme programmatique euh et puis les composants de l'enseignement et caetera quoi / donc on fait on tourne là-autour

Then she clarifies the program of the seminars. In this part of the course unit, the trainees play a more active role as they experience different writing workshops and have to organize one themselves during the internship. She brings into light the fact that, at this state of the training process (students in their first year), it is important to see more than the correct spelling of the words and to look at all the text components:

\section{Corpus extract 2: Planning the training for students in primary education}

et puis en séminaire où ils sont plus actifs sur qu'est-ce qu'écrire on commence par un atelier d'écriture avec eux $\downarrow$ / on leur demande dans une semaine de stage qu'ils ont d'organiser un atelier d'écriture alors on fait des écritures brèves $\downarrow$ / genre petite fabrique de la littérature ou ce genre de chose donc on les fait écrire / et puis euh qu'est-ce qu'on fait encore en écriture / en première année on donc on commence à faire ça après en séminaire on euh / c'est dans ce que je vais faire par la suite donc faut que je me remobilise / ah oui / on travaille sur ouais on commence à les sensibiliser en première année sur le fait que dans les textes il faut regarder d'autres choses que l'orthographe donc on commence à regarder les textes avec leurs différentes composantes / 


\subsection{Conceptualizing knowledge}

With this gesture, the trainer acts as a mediator between theoretical knowledge and the subject's knowledge of the school discipline. It enables the building of knowledge as well as a reflection on written production and its teaching. By doing so, it establishes a professional common culture. According to our analysis, this gesture is accomplished in four main ways:

- Conceptualizes theoretical knowledge and subject knowledge;

- Situates theoretical knowledge and references;

- Provides analytical tools;

- Helps in the elaboration of analytical tools.

The conceptualizing knowledge gesture is shaped by the pedagogical formula set in the training room. Each one of its occurrences implies the transformation of a linguistic, psycholinguistic or didactic knowledge into an operational knowledge that can be used in teaching activities. The trainee provides analytical tools that foster reflection and help the development of concepts. In our data corpus, concepts such as " textual genre", "language activity", "orthographic plurisystem", "historical period in French subject teaching", "thematic progression", "assessment", "aims" are examples of analytical tools.

This gesture is illustrated by the Corpus Extract 3, consisting of a training sequence for the secondary level, in which the students are invited to set appropriate criteria of a literary text:

\section{Corpus extract 3: Conceptualizing the literary text}

$\mathrm{F}: /$ donc j'aimerais que pendant une ou deux minutes vous réfléchissiez à qu'est-ce que c'est le littéraire $\downarrow / d$ 'accord $\uparrow$ / si vous proposez à vos élèves euh un texte littéraire il faudrait quand même que vous sachiez pourquoi est-ce que pour vous il est littéraire $\downarrow$ / hein une p'tite mise au point euh / vous pouvez réfléchir individuellement ou à deux pendant quelques minutes et ensuite on va un peu lister vos catégories / comment est-ce que vous le qualifierez $\downarrow$ / d'accord $\uparrow$ / mais allez-y vraiment de façon intuitive aussi $\downarrow$

Through the elaboration of categories which define the literary text, the trainer gives the tools to help future teachers to approach a large spectrum of written productions.

\subsection{Equipping teachers}

Teachers expect that the training they receive will provide tools to be used in their professional practice. On the other hand, the trainee acts as a mediator of educational techniques and technologies. The Equipping teachers gesture encompasses all means to help the observation, analysis or assessment of pupils' skills: it equips trainees with a toolkit and develops their competencies in didactic engineering. Four occurrences of this gesture were identified in our corpus:

- Presenting and analysing teaching and assessment tools;

- Anticipating the potential use of teaching and assessment tools;

- Helping to design teaching tools;

- Helping to establish objective criteria and scales to observe and assess pupils' skills; 
- Developing techniques toward text annotations and correction.

To accomplish this gesture, the trainer can choose to show the available material, its status (official or not), its characteristics, its potentialities and its limitations. The gesture will vary depending on the secondarisation degree of the tool. The trainer can make a list of the available materials; he can also suggest an analysis of their potential uses and he can show their advantages and disadvantages. Among training activities, several of them involve presenting textbooks and other didactic material. In Corpus Extract 4, the trainer lists all the situations of written production during the second half of primary education: complete a story; write according to a certain model or a certain textual genre; write a story from another perspective, etc. Then he asks his students to give reasons to support the production of the list.

\section{Corpus extract 4: Equipping teachers on situations of written production}

\section{Trainer : pourquoi je vous avais demandé de travailler autour de ces différentes situations} d'écriture $\uparrow$

Student 1 : pour voir les variantes qu'on peut proposer à nos élèves (...)

Trainer : l'idée c'est vraiment que : si on peut faire une synthèse : $c$ 'est que dans la classe durant un cycle: eh bien: on visite le plus possible de situations différentes pour que justement: une part des élèves puissent trouver leur compte et puis puissent avoir aussi: différentes manières deXX changer de destinataire: changer de thème:/

The making of a list of written production situations and the act of thinking about the listing activity are means to help the trainer to explain the importance of dealing with a varied written production.

\subsection{Mobilization of practice and experience}

This gesture contributes to contextualize practices, which is essential to teaching training. It emphasizes and problematizes the articulation of training and professional practice: past experiences as a teacher, a trainee or a student, present practices and future professional action are convened and discussed. The gesture varies according to the highlighted practice: was it experienced as a pupil, a student, a teacher or as the trainer? Is the practice convened through an audio recording or a video? Is it simulated or fictionalized? Thanks to this gesture, the trainer acts as an experienced mediator initiating the circulation of knowledge. The mobilization of the trainee's practice and experience appears mainly in four ways:

- staging the classroom/simulating;

- putting into practice;

- mobilizing the practice;

- analysing the practice.

Mobilization of practice and experience is first addressed by the trainer by implementing situations related to the written production teaching. These situations take into account the constraints of the didactic system and the value given to the social parameters of the texts to be produced. These contextual parameters (production context and communicative situation) bears a predictive value of professional practices, of the training objects as well as of the teaching objects and thus of the meanings to be built at all levels. This implementation makes it possible to better grasp the constraints of teaching and learning situations. Class practice is simulated as well as the communicative situation 
and the planning required for the preparation of the practice.

To illustrate this gesture, the Corpus Extract 5 shows a simulation in which the trainer reads aloud a Pourquoi tale. Throughout this extract, the trainer leads students to see ways of saying and doing, so that they may rely on a model, creating a "listening space":

\section{Corpus extract 5: Exemplifying the reading aloud of a Pourquoi tale}

Trainer: (Reading aloud) donc disais-je / les hommes: retournent au boulot comme d'habitude ramassent le tas de poissons toute la journée et le soir venu: déposent le tas de poissons au centre du village: mais cette fois ils font appel à l'aigle / le soir venu les hommes trop fatigués se sont endormis le ventre creux : les femmes avec leur LONGS: longs: longs: cheveux: descendent par terre et s'emparent du tas de poissons: l'aigle ouvre le bec pour avertir les hommes: mais une femme plus rapide que lui prend un poisson: tape sur la tête et croque à ce moment-là l'aigle ne sait plus parler: MAIS L'aigle: plus rapide que la femme décolle et avec son bec coupe le xxx de cheveux et c'est depuis lors que: (laughs in the room, the trainer closes the book and puts it back on the table) vous êtes d'accord/ du coup c'est depuis lors que vous et moi: nous sommes Xxx sur terre ensemble et euh: xxx BREF: / qu'ai-je fait avec vous:

Student 1: NARRER UN CONTE

Trainer : j'ai narré un conte // quel conte

Student 1 les histoires des pourquoi et du comment

Trainer: les HISTOIRES DES POURQUOI ET DU COMMENT: c'est ce qu'on appelle les contes /

Student 2: les légendes

Trainer: pas les légendes: JUSTEMENT PAS / les contes de la jeunesse ouais : xxx de la jeunesse oui: ça porte un terme bien spécifique xxx du pourquoi et du comment certes mais ça s'appelle des contes étiologiques: ceux qui donnent les explications sur l'origine du monde: l'origine des phénomènes: l'origine de ce que sont de: de quoi sont faits les animaux etc.: etc.: par quoi ai-je commencé ce / conte/ MARIE $\uparrow$

Student 3 (Marie) : par quoi vous avez commencé ce conte

Trainer : ouais

Student 3 (Marie): euh: / il était une fois: je ne sais plus

Trainer : vous ne savez plus xxx bien avant ça encore: bien avant ça encore / j'ai dit ça moi / j'ai visé VANESSA: j'ai dit fermez votre bouche VANESSA

Student 4 (Vanessa): et ouvrez grand vos oreilles

Trainer : et ouvrez grand vos oreilles: c'est ce qu'on appelle les FORMULETTES D'OUVERTURE / c'est typique du conte oral: le conte oral démarre par ça: démarre par ça pourquoi: parce qu'il doit créer un espace d'écoute: et cet espace d'écoute il se traduit par une petite formulette d'ouverture qui est par exemple cela xxx tout à fait les choses / donc j'ai pas commencé par IL ÉTAIT UNE FOIS: j'ai commencé par VANESSA FERMEZ VOTRE BOUCHE ET OUVREZ GRAND VOS OREILLES:

The mobilization of practice and experience gesture helps to define the tasks that trainees will have to carry out with pupils. This gesture implies that the trainer gives indications about the practical teaching ground and about the tasks to be carried out. When trainees are already in a teaching position, this gesture projects the teaching activity in conditions known to trainees. If the training program includes an internship period, this gesture is linked to other planning and designing gestures. In 
this way, real class teaching conditions are convened in the training venue. Sometimes the training practice may occur with pupils coming to the training institution. In this case, the gesture includes practical interventions of the trainer showing the task to be carried out. The trainer thus simulates the activity to provide an example or present a model of what is expected of a teaching practice.

The mobilization of professional experience gesture may bring together both trainer's and trainee's practices through the presentation of contextualised practical cases. These cases may range from the basic evocation of practice through interactional discourse to the rendering of practice through a narrative (an anecdote, a reported example, the recount of a lived-through experience), or through a material aid (such as an audio or a video recording, or a transcribed version of a teaching sequence).

Mobilization of practice and experience implies that trainees distance themselves from groundwork, making the practice objective in order to describe it, to reflect upon it and even to assess it. Distancing and putting practice into discourse may be done with trainees practices as well as with peers practices, thus convening multiple analytical levels and varied points of view. This enables the trainees to take layered analyses into account: the trainer may suggest an analysis as an example or use the analysis of another professional or get students to analyse the practice. The peer analyses made by an expert or by a trainer are put into contrast with that made by the trainees, or just serve as models. In both cases, the aim is to accompany trainees into becoming reflective experts who are able to develop a constructive and critical posture in their own professional activity as well as in that of their peers.

\subsection{Supporting and regulating: developing, experimenting and adjusting teaching regula- tion gestures}

The trainer works on regulations experienced by teachers during training, so as to develop professional ability. Ways of saying and doing are categorized, reworked and adjusted through interactions. The role of the trainer is to accompany teachers in their regulations with pupils. Empirical research data have shown that the regulation gesture has two concrete realizations:

- supporting and regulating trainees in their training activity;

- assessing trainees.

The support and regulation of trainees in their training activities or in the ground-based practice show what trainees bring forward (conceptual definitions, reference framework enlargement, course design adjustment, choice argumentation) or aim at the transformation of a professional gesture. The trainer interferes in the interaction between trainee and pupils and points out ways of speaking for the teacher. In the Corpus Extract 6, trainer and trainees discuss what interventions are needed - or are not - as they watch a short video portraying an activity of dictation of a story. In this activity, the teacher acts as the hand that writes what a young pupil dictate; he interacts in order to bring pupils to formulate grammatical sentences and in order to add consistent information to the story. 
Student 1: parfois elle corrige pas

Trainer: parfois non $\downarrow$

Student1: elle (tient à?) laisser XXX

Trainer : elle laisse $\downarrow$ parce qu'en fait euh peut-être qu'elle se dit qu'elle ne peut pas courir tous les lièvres à la fois / et qu'il y a quelques fois une impossibilité dans un dans une séquence aussi brève à faire des prises de conscience trop importantes $\downarrow$ oui $\uparrow$

Student 2: mais justement j'étais euh à un moment donné c'était une phrase qui rectifie tira le monstre tire le monstre puis elle a laissé le point à la fin de cette phrase / et finalement je trouve qu'en soi cette phrase a peu de sens / elle aurait dû euh peut-être alerter l'élève sur le fait que euh tirer le monstre on peut rajouter euh le lieu où est-ce qu'il est $\mathrm{X}$

Trainer : non c'est elle le tire c'est a tiré le monstre / mais c'est le verbe tirer // c'est c'est

Student 2: a tiré le monstre $\uparrow$

Trainer : oui elle la tire elle le tire et dans le livre il y a un monstre (donc?)

Student 2: oui oui oui là je $\mathrm{H}$ je vois bien mais / je trouve que la phrase en soi elle fait pas

F: ouais ho c'est sûr qu'elle est pas pas

(we interrupt the transcription as the band is inaudible, the transcript is restarted a few minutes later)

F: oui oui oui c'est vrai c'est vrai $\downarrow$ mais vous verrez que: qu'est-ce qui est difficile dans ce genre de situations c'est qu'il faut réagir super vite / il faut dans le moment où se passe quelque chose choisir / je prends ou je prends pas / j'accepte j'accepte pas euh je rebondis je rebondis pas / je fais cette remarque pour aller plus loin je la fais pas / et je peux vous dire que / c'est un apprentissage / c'est pas évident $\downarrow$ et ça veut dire que plus on devient enfin pour devenir un maitre dans le domaine de la dictée à l'adulte c'est-à-dire pour devenir un enseignant qui accueille les dictées que font les élèves c'est pas en une fois hein c'est un apprentissage qui est long / c'est vraiment quelque chose de difficile / vraiment difficile mais génial / (et?) difficile $\downarrow$ /

The supporting and regulating gesture also concerns the assessment of trainees. The gesture takes place when the trainer gives some expert advice about the professional development in progress. This may have relation to what happens during training or after it when the course is finally assessed. The validation of the trainees' results can be considered a pivoting gesture between regulation and assessment of the training course, as the results are used to indicate the relevance and efficiency of the course. Our observations of training courses show that this gesture appears during training when trainers give feedback on the work achieved by trainees. The trainer's gesture consists of comments pointing out strengths and weaknesses that the trainees have to address or it is implemented through marking.

\subsection{Assessing the training sequence or unit}

During and at the end of the training sequence or unit, the trainer carries out assessments of the trainees. With this gesture, the trainer adjusts the planning in order to adapt to the constraints that are presented, thus following the inner dynamic of the training objects. Assessing the course is carried out in four ways:

- reviewing the course with trainees;

- confrontation and coordination with peers; 
- self-assessment;

- reporting to the training institution.

Assessing gesture may occur through a discussion with students; for the trainer, the purpose of this gesture is to evaluate the relevance of the course. Strengths and weaknesses of the training course emerge from interactions between the people involved. These discussions may lead to adjustments if the course continues to be carried out. The trainer also confronts and coordinates his course experience with peers. The profession of teacher trainer is practised on a collective level. Peer interactions have to be coordinated as trainers share the responsibilities of following their students' progress. If a teacher training unit is shared with a group of trainers, it is necessary to have coordination in order to ensure the cohesion and relevance of the whole course. The confrontation and coordination gesture happens at two different times: (1) during a session when there is a change of trainer; (2) during discussions between trainers. Both in collected interviews or concrete training practices, our data show how trainers take their past experiences into account. The trainer bears a judgment on the training course that he/she has planned and has carried out or on the course in which he/she took part. This selfassessment leads to adjustments, from one academic year to the next, or during the training itself.

Finally, this gesture appears when the trainer has to report to the institution where the course was developed. This implies to report on what has been done and to report on students' assessments. It also implies to justify and maybe to discuss the strengths of the training unit. Sometimes, this gesture is done during a session making it possible to get beyond possible resistance within the group; interactions in this case aim at the legitimacy of the training course itself rather than at the knowledge contents related to the written production as such.

In the Corpus Extract 7, the trainer comments the evaluation questionnaire that student must fill at the end of the training session:

\section{Corpus extract 7: Assessing the training sequence}

Trainer 2: je rappelle / qu'on évalue non pas: les enseignants / MAIS DES ENSEIGNEMENTS: alors j'ai mis aussi les collègues bien sûr qui / même Trainer 4: c'est vrai que vous l'avez pas eu vous l'avez eu un peu Trainer 6 vous l'avez eu un peu: et puis moi aussi un peu: donc on est bien au clair c'est les enseignements: c'est-à-dire une cohérence d'ensemble qu'on vous demande: SI: vous avez des remarques à faire SUR CERTAINS ENSEIGNEMENTS beaucoup plus personnalisés: au dos vous avez de quoi faire: donc vous pouvez prendre un peu de temps pour développer: à certains d'entre nous: certaines de ces remarques: OUI

Student 1: est-ce que je peux en avoir UNE

Trainer 2: PARDON: excusez-moi: et observez bien tout en bas il y a: l'alternance qui est interrogée: ça c'est nouveau: on voudrait bien essayer d'aller un tout petit peu plus loin: ça ça met en cause justement vos rapports avec le FT (internship trainer): quand on dit ça: un rapport c'est plutôt en terme de formation: sachant qu'ils ont pas la fonction de vous certifier: ils ont la fonction de vous former: c'est à dire de donner des indications pour progresser sans vous évaluer: ça c'est nous qui vous évalue: voilà je vous: je vous laisse: un petit moment (...) 


\section{Conclusion}

The trainers' action is put into practice through gestures that guide the attention of the trainees to the training objects. These gestures are part of what we call professional gestures, ways of doing and speaking contributing to the transmission and communication of objects of knowledge. They may be apprehended at a more general level in order to describe fundamental routines and the professional techniques that form the social system of the trainers' activity. These gestures are based on past recognised practices, inherited and rooted in the trainer's experience.

The modelling of gestures outlined in this paper enabled us to specify not only the function of each of these gestures in the construction of shared meanings, but also to specify the temporal and logical relationships between them.

Planning and assessing gestures cover the various elements of the training system: the training contract with the trainees, the course and training activities as well as the different objects of training.

Through the framing and conceptualizing gesture, the trainer aims at the object of the training course, i.e. written production and its teaching. Framing may lead beyond the didactic system and touch on the purpose of the education systems and on the constraints of the teaching system. Also, framing may encompass linguistic and discursive knowledge not directly linked to written production but enabling the trainer to clarify the process of didactic transfer. Framing and conceptualising also relate to the didactic contract, the training device, the activities, the teachers' postures and the pupils' capacities.

Equipping teachers is a gesture situated between the didactic system and the trainees. It consists in presenting and showing the existing tools, so that trainees may use them or develop new ones. This gesture contributes to develop professional skills in teaching engineering: it helps to discover or improve the techniques of the teaching profession.

The regulating gesture deals with trainees' actions. It offers models of actions, it helps to adjust knowledge and professional activities or to assess the work that the trainees perform during the course.

Mobilization of practice and experience is based on practices taken from various learning situations. Related practices may come from professionals alien to the training course. Obviously, this gesture is also based on experiences both of the trainer and trainees; these are shared either through discourse (narrated or summarised) or acted out (with simulations and role play). They may be anticipated, experienced or analysed.

As a result, it is possible to say that the trainer's gestures convene the components of the training system as well as those of the teaching system in various ways. This is what makes trainer gestures specific: taking into account a double system in which the trainer may also point out the gestures of the teacher at training (Fig. 2) shows the position of the trainer's main gestures within the training system articulated with the teaching system. 


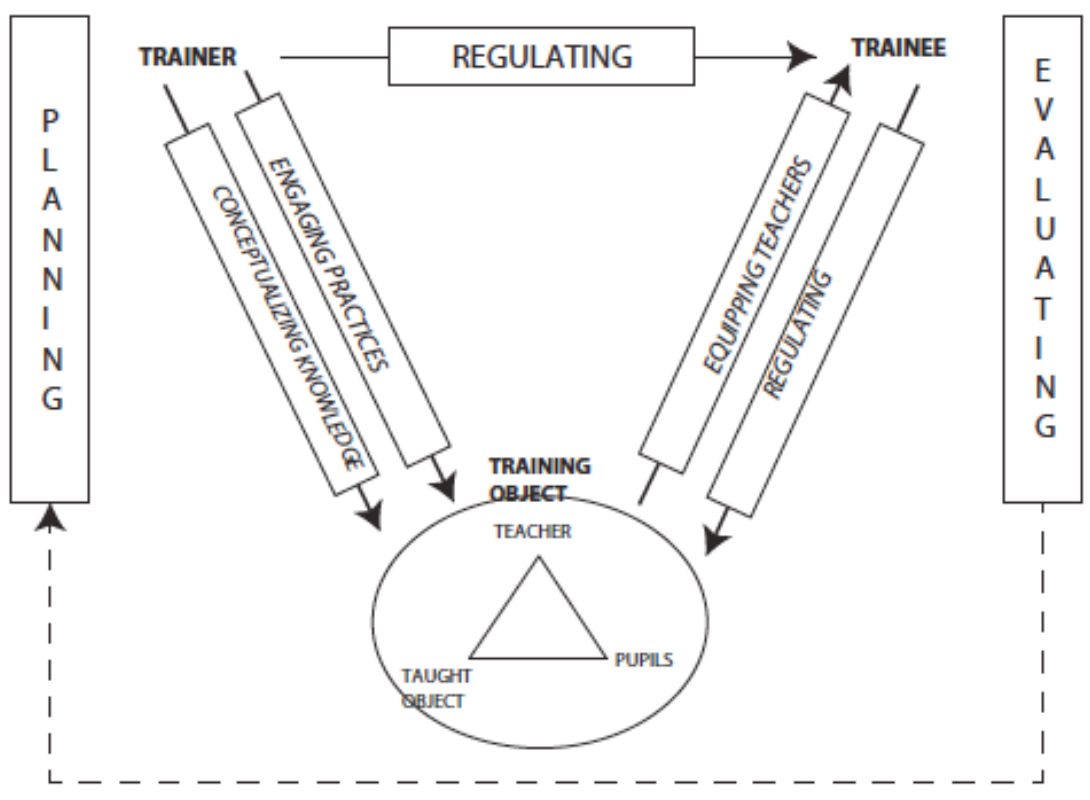

Source: Adapted and translated figure of Dolz, J. \& Gagnon, R. (2018).

The analysis developed in this paper is important to help to organize the action of the trainer. The six main fundamental gestures outlined here are found in all training sequences or units and make it possible to develop strategies in the presentation of the training objects applied to the written production teaching. The trainer may thus embrace a global vision of proactive gestures (planning), interactive gestures (implementation of training courses) and retroactive gestures (assessment). The analysis of training practices showed the complex relationships between gestures of framingconceptualizing, equipping, mobilization of practice and regulating. Our observations led to precise descriptions of each of these gestures through trainers' ways of doing and saying: the highlighted examples show the role of the gestures in the deployment of the training object and the presence of specific tools according to the gestures used.

The trainers' gestures convene the training knowledge contents in various ways. The framing and conceptualizing gestures deal with subject-related knowledge as well as prescriptions, learning processes and learners' writing procedures. In contrast, the equipping teachers gesture covers the teaching and assessment devices.

These gestures are of the upmost importance during training. The mobilization of practice gesture bears an integrative role as it deals with three angles at the teaching system (knowledge, teacher and pupil). This large spectre of knowledge is also at the core of the regulating gesture: based on interactions between trainers and trainees, it helps supporting and overcoming obstacles and resistance. The planning and assessing gestures are based on institutional demands and are therefore of a more general nature. 


\section{References}

AEBY DAGHÉ, S.; DOLZ, J. Des gestes didactiques fondateurs aux gestes spécifiques à l'enseignement/apprentissage du texte d'opinion. In : BUCHETON, D.; CHABANNE, J.C. (ed.). Les gestes professionnels de l'enseignant. Bruxelles : De Boeck, 2009.

BERNIÉ, J.-P.; GOIGOUX, R. Quels concepts pour quelle analyse de l'activité du professeur ? La lettre de l'AIRDF, 36, 3-4, 2005.

BRONCKART, J.-P. Activité langagière, texte et discours. Paris : Delachaux \& Niestlé, 1997.

BROUSSEAU, G. Théorie des situations didactiques. Grenoble: La Pensée Sauvage, 1998.

BRUNER, J. S. Le développement de l'enfant: Savoir faire, savoir dire. Paris : Presses universitaires de France, 1983.

BUCHETON, D. Le développement des gestes professionnels dans l'enseignement du français: un défi pour la recherche et la formation. Bruxelles: De Boeck, 2008.

BUCHETON, D.; SOULÉ, Y. Les gestes professionnels et le jeu des postures de l'enseignant dans la classe: un multi-agenda de préoccupations enchâssées. Éducation et didactique, 3, 3, 29-48, 2009.

BUCHETON, D.; ALEXANDRE, D.; JURADO, M. Refonder l'enseignement de l'écriture: Vers des gestes professionnels plus ajustés du primaire au lycée. Paris: Retz, 2014.

CHEVALLARD Y. (1999). L'analyse des pratiques enseignantes en théorie anthropologique du didactique. Recherches en Didactique des Mathématiques, 19, 221-266.

CLOT, Y.; FAÏTA, D. Genre et style en analyse du travail. Concepts et méthode. Travailler, 4, 7-42, 2000.

CROCE-SPINELLI, H. Gestes professionnels. In: JORRO, A. (ed.). Dictionnaire des concepts de la professionnalisation. Louvain-la-Neuve: De Boeck, p. 145-148, 2014.

DESJARDINS, J. \& DEZUTTER, O. (2009). Développer des compétences professionnelles en formation initiale à l'enseignement préscolaire et primaire : regard sur l'organisation des programmes en contexte québécois. Canadian Journal of Education, 32(4), 873-902.

DOLZ, J \& GAGNON, R. Former à enseigner la production écrite. Lille : Presses universitaires du Septentrion, 2018.

DUFAIS, J.-L. Du geste professionnel au geste didactique: une intégration stratégique pour la recherche en didactique et la formation des enseignants In: S. AEBY DAGHE; BULEA BRONCKART, E.; CORDEIRO, G. S.; DOLZ, J.; LEOPOLDOFF, I.; MONNIER, A.; RONVEAUX, Ch.; VEDRINES, B. (Ed.). Didactique du français et construction d'une discipline scientifique. Lille: Septentrion, p. 155-165, 2019.

DUGAL, J.-P.; LÉZIART, Y. La circulation des savoirs entre recherche et formation: l'exemple des concepts didactiques lors d'une action de formation de conseillers pédagogiques. Revue française de Pédagogie, 149, 37-47, 2004.

FERREIRO, E. (1998). Alfabetización : teoría y práctica. México : Siglo XXI.

FRITH, U. (1980). Cognitive Processes in Spelling. New York: Academic Press.

GAGNON, R. Former à enseigner l'argumentation orale: De l'objet de formation à l'objet enseigné en classe de culture générale. 2010. Genève: Université de Genève, Thèse de doctorat en sciences de l'éducation (non publiée).

GAGNON, R. \& SURIAN, M. (2014). Quels savoirs pour l'enseignement de la production écrite au secondaire dans les plans de formation suisses romands? Revue suisse des sciences de l'éducation, 36 (1), 109-134. 
GOIGOUX, L.; RIA, L.; TOCZEK-CAPELLE, M.- C. (ed.). Les parcours de formation des enseignants débutants. Clermont Ferrand: Presses Universitaires de Blaise Pascal, 2009.

JAUBERT, M.; REBIÈRE, M. Gestes et genres professionnels. La Lettre de l'Association AIRDF, 36, 23-24, 2005.

JORRO, A. Professionnaliser le métier d'enseignant. Issy-les-Moulinaux: ESF Éditions, 2002.

JORRO, A. Le corps parlant de l'enseignant. Communication présentée au 9e colloque de l'AIRDF. Québec: Université de Laval, 2004. En ligne: <http://www.colloqueairdf.fse.ulaval.ca/fichier/ Symposium_Bucheton/Jorro.pdf> (consulté le 8 août 2017).

LENOIR, Y. \& VANHULLE, S. (2006). Étudier la pratique enseignante dans sa complexité. Une exigence pour la recherche et la formation à l'enseignement. In : A. HASNI, Y. LENOIR \& L. JOËL (Eds.), La formation à l'enseignement des sciences et des technologies au secondaire dans le contexte des réformes par compétences (pp. 193-245). Québec : Presses de l'université du Québec.

RUNTZ-CHRISTAN, E. Enseignant et comédien, un même métier ? Issy-les-Moulineaux: ESF Éditions, 2000.

SCHNEUWLY, B. (1988). Le langage écrit chez l'enfant : la production des textes informatifs et argumentatifs. Paris : Delachaux et Niestlé.

SCHNEUWLY, B. Les outils de l'enseignant. Un essai didactique. Repères, 22, 19-38, 2000.

SCHNEUWLY, B.; DOLZ, J. Des objets enseignés en classe de français: le travail de l'enseignant sur la rédaction de textes argumentatifs et sur la subordonnée relative. Rennes: Presses universitaires de Rennes, 2009.

SCHUBAUER-LEONI, M. L.; LEUTENEGGER-RIHS, F.; LIGOZAT, F.; FLÜCKIGER, A. Un modèle de l'action conjointe professeur-élèves: les phénomènes didactiques qu'il peut/doit traiter. In: SENSEVY, G.; MERCIER, A. (ed.). Agir ensemble. L'action didactique conjointe du professeur et des élèves. Rennes: Presses Universitaires de Rennes, p. 51-91, 2007.

SENSEVY, G. Théories de l'action et action du professeur. In: BAUDOIN, J.-M.; FRIEDERICH, J. (Éds). Théories de l'action et éducation. Bruxelles: De Boeck, p. 203-224, 2001.

SENSEVY, G. Des catégories pour décrire et comprendre l'action didactique. In: SENSEVY, G.; MERCIER, A. (Éds). Agir ensemble. L'action didactique conjointe du professeur et des élèves. Rennes: Presses universitaires de Rennes, p. 13-49, 2007.

SENSEVY, G. Notes sur la notion de geste d'enseignement. Travail et formation en éducation [En ligne], 5, 2010. En ligne: <http://tfe.revues.org/1038> (consulté le 08/08/2017).

SILVA, Carla Messias. O agir didático do professor de língua portuguesa e sua reconfiguração em textos de autoconfrontação. 2013. Tese (Doutorado) - Linguística Aplicada e Estudos da Linguagem, Pontifícia Universidade Católica de São Paulo, São Paulo, 2013.

TELLIER, M.; CADET, L. (ed.). Le corps et la voix de l'enseignant: théorie et pratique. Paris: Maison des langues,2014. 
